ORIGINAL ARTICLES

\title{
Knowledge, Attitudes, and Practices of Corporal Punishment in Bahamian Homes
}

\author{
William J. Fielding \\ (i) 0000-0001-5433-9673 \\ Virginia C. Ballance \\ (iD) $\underline{0000-0003-1067-8205}$ \\ University of The Bahamas
}

\begin{abstract}
In an Internet-based study, 1,583 Bahamian adults living in The Bahamas were asked about their knowledge, attitudes, and practices relating to corporal punishment. The study confirmed the attitudes and practices towards corporal punishment reported in other studies. Both male and female respondents were physically punished as children (92.4\% of males and $87.1 \%$ of females). The study indicated that a limited number of participants had knowledge of the detrimental effects of corporal punishment; for example, $28 \%$ of male and $36.2 \%$ of female participants agreed that corporal punishment was associated with learning problems at school. Respondents with more knowledge about the effects of corporal punishment were less likely to use disciplinary methods of concern. There was a strong link between knowledge and attitudes and between attitudes and experiences of physical punishment in the childhood of respondents. The data suggest that education about the detrimental effects of corporal punishment could help to reduce its use and prevent children from suffering the unintended consequences of corporal punishment.
\end{abstract}

Some children learn differently. Some kids you can beat them until Jesus come and they still won't learn, instead they rebel and produce bad behaviours. Some on the other hand respond postiviely [sic] to it meaning they refuse to do it again because they know the outcome or they think twice before doing it. But once your child is brought up in a sensible way honestly the beating using belts, shoes, etc wont [sic] be needed. Participant A.

\section{Introduction}

A review of the literature on corporal punishment in The Bahamas, focusing on its use in schools (Fielding \& Ballance, 2020), indicated that it has a long history both in The Bahamas and the Caribbean region. Its use continues today (Sutton \& Álvarez, 2016) even though The Bahamas signed the United Nations Convention on the Rights of the Child (UNICEF, 1989), which aims to protect children from violence, in 1991, and despite the increasing evidence that corporal punishment is harmful to children (e.g., Gershoff, 2010). Within Bahamian society, studies have demonstrated negative consequences of childhood punishment when it becomes harsh (Knowles, 1999; Roth et al., 2020), which included reduced academic achievement (Dede Yildirim \& Roopnarine, 2019). 
The current laws of The Bahamas outlaw corporal punishment in care homes for residents of any age (Early Childhood Care [National Standards] Regulations 2015 [Bahamas]), and it is illegal to use corporal punishment on children aged five or under in pre-schools (Early Childhood Care Act [2004] and Early Childhood Care [National Standards] Regulations 2015 [Bahamas]; Residential Care Establishments Act [2004]). ${ }^{1}$ Otherwise, corporal punishment is permitted in the school system, homes, and criminal justice system. Brennen et al. (2016) indicated that the Bahamian view of abuse, in relation to corporal punishment, would be considered something close to grievous bodily harm in other jurisdictions; therefore, although various studies indicate that about $4 \%$ of children are considered abused as a result of discipline, this only represents the most severely punished group (Fielding et al., 2016).

Support for corporal punishment in The Bahamas is widespread (Fielding \& Ballance, 2020). Otterbein and Otterbein's (1973) study in the 1960s pointed to its enduring use and its association with religious belief. In recognition of this faithbased influence, Save the Children (2015) partnered with faith communities to try to address the issue of corporal punishment and faith teachings. The role of faith leaders in forming current attitudes in Bahamian society has been demonstrated by Fielding and Ballance (2019). These attitudes often reinforce a traditional family hierarchy base. In a study on Caribbean parents in the United States, Dede Yildirim (2013) noted that child behaviours were influenced by parental religious beliefs, level of punishment used on the child, and parenting style.

In Jamaica, it has been shown that despite its

\footnotetext{
${ }^{1}$ Although the use of corporal punishment is illegal in residential care homes, in early 2021 , a video of children being beaten was shown on social media,
}

participation in various United Nations conventions on human rights, practices of the population contravene these conventions and the laws enacted to protect children (Smith, 2016). Smith's (2016) review made it clear that the use of violence on children creates violent adults in the Jamaican context. This is an observation that should not be ignored lightly in the Bahamian context, where corporal punishment of children is used throughout society (Allen Carroll et al., 2016). Landon et al. (2017) viewed corporal punishment through a human rights lens and called for public education on the matter in order to reduce the cycle of violence that such punishment can perpetuate.

In Jamaica, the tension between children not behaving as required by mothers often leads to mothers asserting their authority by using "physical punishment, psychological control, forced compliance, and deprivation of privileges" (Burke \& Kuczynski, 2018, p. 6). This indicates that mothers use a range of methods to discipline children, with a preference for physical punishment and forced compliance. The reliance on corporal punishment to discipline children was also demonstrated in Barbados (Payne, 1989). The fact that negative parenting practices have been linked to high levels of violence in Jamaican society (Smith \& Mosby, 2003) makes the use of corporal punishment inside the home a concern for all society. In the Caribbean, it has been advanced that "discipline was the main form of interaction between parents and children" (Barrow \& Ince, 2008, p. 13). Therefore, it is important to know how this interaction unfolds as methods of discipline can have life-long effects (Gershoff, 2010).

The use of corporal punishment in homes does not exist in isolation because corporal

resulting in the Minister of Social Services and Urban Development stating, "no more corporal punishment in children's homes" (Smith, 2021). 
punishment is permitted in Bahamian schools. However, although its use in schools is regulated (Johnson, 2016), no similar monitoring can be expected within homes. Therefore, the Bahamian home may be a space in which corporal punishment becomes abuse, as already noted by Brennen et al. (2016). Their study also indicated that, in adulthood, respondents now considered the corporal punishment they received when children abuse.

Our study was undertaken to examine the knowledge, attitudes, and practices with respect to corporal punishment in the Bahamian context. Although attitudes and practices have been previously studied in this community (Fielding et al., 2016; Fielding \& Ballance, 2020), less is known about the knowledge that Bahamians have about the consequences various disciplining methods might have on children. It is this latter aspect that this study sought to address, recognizing that attitudes and practices are not independent of knowledge.

\section{Methodology}

Questions from the 2017 UNICEF study on corporal punishment were used as the core of this study. However, a smaller number of questions were asked in order to reduce the survey's length; typically, it took eight minutes to be completed. Added to the 2017 UNICEF survey were questions relevant to the Bahamian context, which were suggested by students from University of The Bahamas. Students used their social media groups to recruit participants. The target population was persons aged 18 years or older who were Bahamian citizens ordinarily residing in The Bahamas. This snowball sampling method was particularly appropriate during the Covid-19 pandemic in Fall 2020 when faceto-face contact was to be minimized. It was anticipated that 2,300 participants would be recruited; however, only 2,158 persons entered the survey. The survey questions focused on respondent demographics, knowledge, attitudes, and, where appropriate, practices of discipline on children in their care who were aged 0-14 years.

The study was approved by the Institutional Review Board of University of The Bahamas.

\section{Results}

After the data were cleaned, 1,583 responses were retained in the analysis from respondents who met the requirements of the target population: adults aged 18 or older who were Bahamian citizens ordinarily resident in The Bahamas. Further, those from the target population who provided few or no responses were excluded from the data set. As respondents could choose not to answer any question, not all participants completed the survey, so for some questions fewer answers were obtained.

The respondents were made up of $70.3 \%$ females (of 1,561 respondents). The modal age group was $18-24 \quad(40.9 \%$ of 1,583 respondents) and the modal level of completed education was econdary/high school $(47.9 \%$ of 1,577). The modal household income bracket in 2019 was $\$ 30,000-\$ 49,999$. These results are in line with the general biases in favour of females participating in online surveys in The Bahamas (Fielding, 2020) and in favour of younger age groups (which occurs when using university-aged persons to start the snowball sample).

Six hundred and thirty-eight participants $(40.5 \%$ of 1,575$)$ were parents/guardians who had responsibilities for children aged 14 or under in their homes. This group was then asked not only about their knowledge of and attitudes about corporal punishment, but also about their practices with respect to child discipline. 
Respondents had a history of being victims of corporal punishment: $92.4 \%$ of male and $87.1 \%$ of female respondents were physically punished as children, so male participants were more likely than female participants to have been hit $\left(\chi^{2}(1, N=1,557)=8.89, p=\right.$ .003). The methods of discipline to which they had been subjected are outlined in Table 1. The most common implements used to hit participants were belts, shoes, switches and cords, clothes hangers, and anything at hand. For this last group, "anything" or "everything" or "whatever was at hand" could include items that could cause harm to the child. Being hit with an object raises the risk of the victim being abused (Zolotor et al., 2008), so almost $60 \%$ of study participants possibly may have been abused as children.

\section{Table 1}

Method of Discipline Experienced by Study Participants

\begin{tabular}{lc}
\hline Method of discipline & $\%$ of respondents \\
\hline Hit with the hand & 76.4 \\
Shouted at & 60.8 \\
Hit with an object & 58.2 \\
Given extra chores & 38 \\
Other (please specify) & 30.1 \\
Never punished & 4.2 \\
\hline
\end{tabular}

Note. Multiple answers allowed.

When respondents were hit with an object, the most commonly reported items were belts (78.5\% of 855 responses), shoes (8.5\%), and switches $(7.1 \%)$, see Figure 1. This is consistent with videos on social media showing children being beaten with belts (owing to Facebook rules, these videos are removed for violating community standards). This gave context to the personal experiences of respondents of corporal punishment. Some of the responses, anything and whatever was in reach, suggest that the punishments may have been inflicted without deliberation, an occurrence that would appear to be in agreement with what Participant B said: "As a parent you do the best you can to rare [sic] your children. Sometimes you will lose your cool and react out of anger."

\section{Figure 1}

Word Cloud of Items Used to Inflict Physical Punishment on Respondents When Children

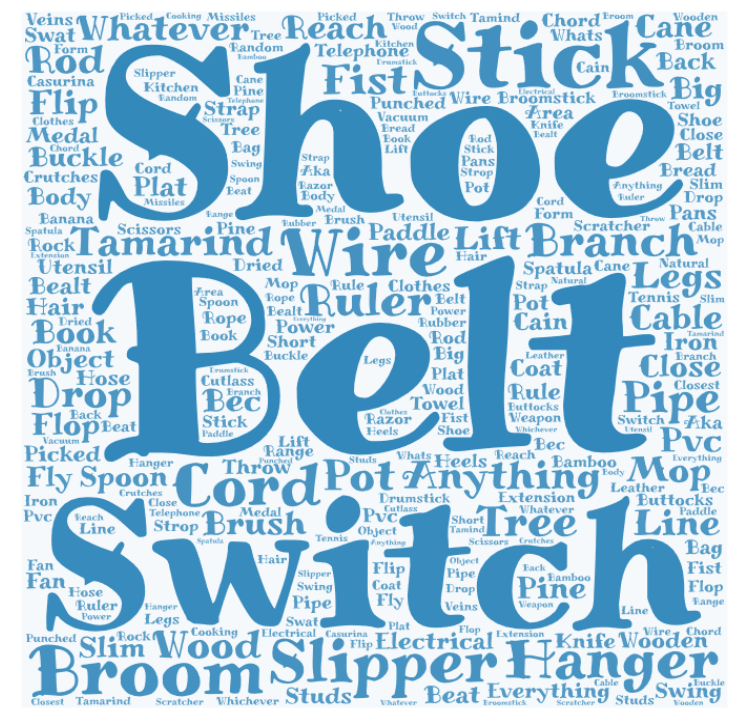

Overall, 65.6\% (1,557 respondents) approved of the use of corporal punishment of children. However, this hides an important difference between male and female respondents, as $74.3 \%$ of males and $62 \%$ of females approved of hitting children as a means of punishment $\left(\chi^{2}(1, N=1,536)=21.5, p<\right.$ $.001)$. Therefore, the data will be disaggregated by sex of respondent where there are statistically significant differences between the sexes.

\section{Social Expectations}

Although both males and females tended to agree about various social norms and parenting, their level of agreement differed in most aspects (see Table 2). However, it should be noted that, for some aspects, there was little agreement, with both males and 
females having scores close to three, indicating neither agreement nor disagreement. This can be seen in the case of parents being subjected to others telling them how they should raise their children. Despite the males being more in favour of corporal punishment than females, they appeared more protective of their daughters than females when it came to the use of corporal punishment. Table 2 also indicates an apparent doubt as to whether corporal punishment is effective, even though it is approved and used. Participant $\mathrm{C}$ combined a Biblical justification for discipline together with a secular proverb, stating that "The bible say $[s i c]$ if you spare the rod you will spoil the child and old saying bend the tree while it is young when it gets old and you try to ben [sic] it it will brake [sic]." This illustrates how two traditions have been fused to justify corporal punishment. It should be noted that most participants thought that physical punishment was not the only way of disciplining a child, and respondents seemed to be unsure how effective physical punishment was as a form of discipline. Participant D indicated that parents were too willing to use corporal punishment: "In The Bahamas persons take 'do not spear [sic] the rod' too seriously and often spank their children for every little thing."

\section{Table 2}

Expectations of Society on Child Discipline.

\begin{tabular}{lcccc}
\hline \multicolumn{1}{c}{ Societal expectations } & Male & Female & $\mathrm{X}^{2}$ \\
\hline Men \& women should have equal responsibility for raising children. & 1.29 & 1.14 & $<.001$ \\
$\begin{array}{l}\text { Parents who encourage their children to talk to them develop } \\
\text { stronger self- esteem in the child. }\end{array}$ & 1.58 & 1.41 & $<.001$ \\
When I was a child, children were more disciplined. & 1.94 & 1.81 & .035 \\
Children can learn to behave without being spanked/slapped. & 1.97 & 1.84 & .037 \\
$\begin{array}{l}\text { Slapping/spanking are effective methods of disciplining a child. } \\
\text { A parent who does not punish their child when they misbehave is }\end{array}$ & 2.55 & 3.73 & 3.05 & $<.001$ \\
not a good parent. & 3.06 & 3.11 & .507 \\
$\begin{array}{l}\text { No one has the right to tell a parent how to raise the child. } \\
\text { A parent has the right to discipline their child in any way they } \\
\text { believe is right. }\end{array}$ & 3.11 & 3.11 & .906 \\
Hitting a girl is worse than slapping a boy. & 3.46 & 3.95 & $<.001$ \\
\hline Note: Agr & & & & \\
\hline
\end{tabular}

Note: Agreement is measured on a scale 1 = totally agree, 5 = totally disagree

\section{Attitudes Towards Selected Ways of Disciplining a Child}


Discipline should be done in love, never in anger. This is a Bible-based practice and when administered correctly... It makes a world of a difference in a parent's/child's life. It is only when this practice is misused does it yield a negative result. Participant $\mathrm{E}$

Respondents were asked to indicate their agreement/disagreement with various methods of child discipline on a five-point Likert scale $(1=$ totally agree, $5=$ totally disagree). The mean scores for males and females are given in Table 3. Table 3 indicates the disagreement between males and females in their attitudes towards various disciplinary actions on children, with males Table 3

Males and Females with Various Disciplinary Actions.

\begin{tabular}{lllc}
\hline \multicolumn{1}{c}{ Action } & Male & Female & $t$ - test \\
\hline & $M$ & $M$ & $p=$ \\
\hline Spanking a child's rear & 2.06 & 2.37 & $<.001$ \\
Slapping a child on the arm or leg & 2.30 & 2.61 & $<.001$ \\
Beating a child with hand, belt, stick or other hard object & 2.70 & 3.20 & $<.001$ \\
Pinch a child & 2.82 & 3.38 & $<.001$ \\
Pulling a child's ear & 3.80 & 4.26 & $<.001$ \\
Slapping a child's face, head or ear & 4.45 & 4.77 & $<.001$ \\
Taking away a child's privileges to teach them a lesson & 1.40 & 1.38 & .629 \\
Yelling or screaming at a child & 3.39 & 3.65 & $<.001$ \\
Grabbing and shaking a child & 4.12 & 4.65 & $<.001$ \\
Calling a child stupid, lazy and similar & 4.54 & 4.81 & $<.001$ \\
Threatening to leave or abandon a child & 4.79 & 4.86 & .044 \\
Sexual abuse of a child & 4.92 & 4.99 & .001 \\
Using corporal punishment on a disabled (special needs) child & 4.52 & 4.77 & $<.001$ \\
\hline
\end{tabular}

showing more agreement than females with the selected punishments. It also shows that even though physical discipline actions are generally accepted by both males and females, hitting around the face is not. As Participant F wrote, "I think children should be disciplined but not abused. A spank to the leg is ok but not a slap to the face or ear." Participant $G$ provided a medical perspective: "I am a medical doctor I see the results of shaking, child neglect and child abuse daily in the ER [Emergency Room] and radiology dept." This suggests that these harsh punishments may be more common than might be appreciated.

Note: Agreement is measured on a scale $1=$ totally agree, $5=$ totally disagree. 


\section{Practice and Use of Corporal Punishment on Children Aged 14 and Under}

Parents should understand the difference between discipline and abuse. Participant $\mathrm{H}$

Six hundred and thirty-eight participants (40.5\% of 1,575$)$ were parents/guardians or had responsibilities for at least one child aged 14 or under in their homes, and $53.5 \%$ of these caregivers cared for only one child. When there was more than one child in the respondent's care, the respondent was asked to choose one child and report on the methods used to discipline this specific child. This was done because it was appreciated that disciplinary methods might vary by age of child.

Caregivers looked after a mean of 1.75 (SE = .052) children. Of the children whose discipline methods were reported, $52.3 \%$ were male and the mean age was 8.9 ( $S E=$ .17) years. While some of the harsher methods were not used frequently in the four weeks prior to completing the survey, the frequency hitting the child as hard as the caregiver could sometimes or frequently provide an idea of the percentage of children who are at risk of physical abuse (see Table 4).

\section{Table 4}

Methods Used by Caregivers to Discipline Children Aged 14 and Under

\begin{tabular}{|c|c|c|c|c|}
\hline Class & Method used in previous last four weeks & Frequently & Sometimes & Never \\
\hline & & $\%$ & $\%$ & $\%$ \\
\hline MP & Hit or spanked him/her on the bottom & 4.2 & 45.1 & 50.7 \\
\hline MP & Hit or spanked him/her on the hand, arm, or leg & 4.8 & 54.4 & 40.8 \\
\hline MP & Twisted his/her ear or pulled his/her hair & 0.3 & 3.4 & 96.3 \\
\hline MP & Shook him/her with hands & 0.3 & 8.3 & 91.3 \\
\hline NV & $\begin{array}{l}\text { Child was ignored when his/her behaviour was } \\
\text { incorrect/bad }\end{array}$ & 4.6 & 30.5 & 64.9 \\
\hline NV & $\begin{array}{l}\text { Child was sent to his/her room, or to the corner or to sit } \\
\text { somewhere alone }\end{array}$ & 7.0 & 44.7 & 48.2 \\
\hline NV & $\begin{array}{l}\text { Things he/she likes were taken away, or child was } \\
\text { forbidden to do something he/she likes or punished } \\
\text { him/her to go out }\end{array}$ & 21.7 & 63.9 & 14.4 \\
\hline PA & $\begin{array}{l}\text { Warned the child with a threat that he/she would be } \\
\text { punished }\end{array}$ & 29.3 & 58 & 12.7 \\
\hline PA & Yelled or screamed at the child & 5.5 & 59.7 & 34.8 \\
\hline PP & Praised the child about his/her good behaviour & 77.7 & 19.8 & 2.6 \\
\hline PP & Explained why his/her behaviour was incorrect & 55.3 & 34.7 & 10.1 \\
\hline PP & Child was given to do something else & 12.6 & 66 & 21.4 \\
\hline SP & Hit him/her on the face, head or ears & 1.1 & 4.2 & 94.7 \\
\hline SP & $\begin{array}{l}\text { Beaten, i.e. hit him/her over and over as hard as one } \\
\text { could }\end{array}$ & 0.3 & 5.3 & 94.4 \\
\hline
\end{tabular}

Note. Class: MP: Minor physical punishment; NV: Non-violence discipline; PA: Psychological aggression; PP: Positive parenting practices; SP: Severe physical punishment (UNICEF, 2017). 
We also note that $7 \%$ of caregivers never used any of the positive parenting practices listed in Table 4, while 1\% frequently used these positive parenting methods. In terms of psychological abuse, this risk was higher than for physical abuse, as most children were likely to have been threatened or shouted at (see Table 4). This form of aggression was used by most caregivers, irrespective of the age of the child. When the items in Table 4 are classified by parenting practices, (UNICEF, 2017), it is clear that these practices differ between age groups of the children, as seen in Table 5. It should also be noted that respondents used a combination of positive and less positive parenting practices.

\section{Table 5}

\section{Parenting Practices Used by Age Group of Child}

\begin{tabular}{lccccc}
\hline \multicolumn{7}{c}{ Age group of child } \\
\hline Classification of methods & $0-2$ years & $3-7$ years & $8-12$ years & $13-14$ years & Overall \\
\hline & $\%$ & $\%$ & $\%$ & $\%$ & $\%$ \\
\hline Use of psychological aggression & 71.6 & 94.9 & 94.0 & 89.6 & 90.8 \\
Use of minor physical discipline & 68.5 & 78.7 & 67.0 & 50.0 & 68.0 \\
Use of harsh physical discipline & 1.3 & 7.1 & 10.8 & 11.2 & 8.5 \\
Never used non-violent discipline methods & 25.3 & 4.5 & 6.9 & 5.7 & 8.2 \\
Frequently used positive parenting & 8.8 & 9.6 & 4.6 & 6.2 & 7.0 \\
\hline
\end{tabular}

\section{Knowledge About the Effects of Corporal Punishment}

Children should feel safe to Express themselves to their parents without fear of being hit or abused in any form or fashion. Participant I

Male and female respondents had differing degrees of knowledge about the effects of corporal punishment (see Table 6). However, it is noteworthy that for some aspects of corporal punishment, almost a third of respondents did not appear to know enough to agree or disagree with the statements as they chose do not know. If the answers to the knowledge tested in Table 6 were considered an examination of knowledge, while females were more knowledgeable than males (females: $M=6.1, S E=.09$, and males: $M=$ $5.2, S E=.14)$, overall, $48.3 \%$ of the participants would have failed to get a mark of $50 \%$. Consequently, it can be appreciated that many respondents lacked knowledge about the longer-term detrimental effects of corporal punishment, so those who use potentially harmful methods to discipline their children are doing so without the knowledge to fully appreciate the possible effects of their actions. 
Table 6

Knowledge of the Effects of Corporal Punishment.

\begin{tabular}{|c|c|c|c|c|c|}
\hline Result of corporal punishment & Sex & Agree & Disagree & Do not know & $x^{2}$ \\
\hline & & $\%$ & $\%$ & $\%$ & $p=$ \\
\hline \multirow{2}{*}{ Makes the child stop the unwanted behaviour } & Male & 63.6 & 21.0 & 15.4 & \multirow{2}{*}{$<.001$} \\
\hline & Female & 52.3 & 29.3 & 18. & \\
\hline $\begin{array}{l}\text { The child will never repeat the unwanted } \\
\text { behaviour }\end{array}$ & Both & 19.8 & 58.8 & 21.4 & .11 \\
\hline The child learns the good and the bad & Both & 72.5 & 15.4 & 12.2 & .24 \\
\hline \multirow{2}{*}{ Produces only short-term effect } & Male & 36.4 & 40.6 & 23 & \multirow{2}{*}{$<.001$} \\
\hline & Female & 48.0 & 31.3 & 20.7 & \\
\hline \multirow{2}{*}{$\begin{array}{l}\text { Immediate physical health problems, such as } \\
\text { such injuries, bruises and fractures }\end{array}$} & Male & 36.2 & 39.7 & 24.2 & \multirow{2}{*}{$<.001$} \\
\hline & Female & 47.5 & 32.5 & 20.0 & \\
\hline \multirow{2}{*}{$\begin{array}{l}\text { Long term physical health problems, such as } \\
\text { changes in the development of brain and long- } \\
\text { term physical impairments }\end{array}$} & Male & 29.7 & 40.0 & 30.3 & \multirow{2}{*}{$<.001$} \\
\hline & Female & 38.5 & 30.2 & 31.3 & \\
\hline \multirow{2}{*}{ Difficulties in dealing with other people } & Male & 34.1 & 47.2 & 18.7 & \multirow{2}{*}{$<.001$} \\
\hline & Female & 43.7 & 34.6 & 21.7 & \\
\hline \multirow{2}{*}{$\begin{array}{l}\text { Learning problems - worse results in performance } \\
\text { at school }\end{array}$} & Male & 28 & 52.3 & 19.7 & \multirow{2}{*}{$<.001$} \\
\hline & Female & 36.2 & 40.4 & 23.4 & \\
\hline \multirow{2}{*}{$\begin{array}{l}\text { Finding it hard to express feelings in a way that } \\
\text { other people can understand }\end{array}$} & Male & 45.1 & 34.9 & 20.0 & \multirow{2}{*}{$<.001$} \\
\hline & Female & 60.0 & 25.6 & 14.5 & \\
\hline \multirow{2}{*}{$\begin{array}{l}\text { Emotional health problems including anxiety, } \\
\text { depression, aggression or even wanting to kill him } \\
\text { or herself }\end{array}$} & Male & 40.2 & 34.9 & 24.9 & \multirow{2}{*}{$<.001$} \\
\hline & Female & 57.2 & 23.8 & 18.9 & \\
\hline \multirow{2}{*}{$\begin{array}{l}\text { Being more likely to do dangerous things like } \\
\text { using drugs or having sex at a very young age }\end{array}$} & Male & 27.5 & 45.3 & 27.2 & \multirow{2}{*}{$<.001$} \\
\hline & Female & 37.6 & $37.6 \%$ & 24.7 & \\
\hline \multirow{2}{*}{$\begin{array}{l}\text { Children who experience violence accept this as } \\
\text { normal and mirror the same behaviour }\end{array}$} & Male & 51.5 & 26. & 22.2 & \multirow{2}{*}{$<.001$} \\
\hline & Female & 65.1 & 19.7 & 15.2 & \\
\hline
\end{tabular}


Participant $\mathrm{J}$ seemed to connect lack of discipline (which from Table 2 probably can be seen to mean corporal punishment) with crime, asserting that "Children needs [sic] to be discipline $[s i c]$ in this country to avoid some of this crime... with youngers [sic] today" rather than appreciating that corporal punishment can be a driver of crime (Fielding, 2016). Despite the work of Deveaux and Rolle (2016), the link between risky childhood behaviours and parenting has not been appreciated by the public. Table 6 indicates that many caregivers may be behaving in ways they would not if they had more knowledge. Except for positive parenting practices and non-violent discipline methods, there were statistically significant correlations between the frequency of use of these disciplinary methods and knowledge, with those using the discipline measures of concern more frequently displaying lower knowledge scores (see Table 7).

\section{Table 7}

Partial Correlations with Knowledge of Disciplinary Effects and Methods of Discipline Used, Adjusted for Sex and Age of Child

\begin{tabular}{lcc}
\hline $\begin{array}{l}\text { Classification of } \\
\text { methods }\end{array}$ & $\begin{array}{c}\text { Correlation } \\
\text { with } \\
\text { knowledge } \\
\text { score }\end{array}$ & $p=$ \\
\hline Positive parenting & -.01 & .830 \\
$\begin{array}{l}\text { Use of non-violent } \\
\text { discipline methods }\end{array}$ & .02 & .703 \\
$\begin{array}{l}\text { Use of psychological } \\
\text { aggression }\end{array}$ & -.12 & .008 \\
$\begin{array}{l}\text { Use of minor } \\
\text { physical discipline }\end{array}$ & -.24 & $<.001$ \\
$\begin{array}{l}\text { Use of harsh } \\
\text { physical discipline }\end{array}$ & -.11 & .010 \\
\hline
\end{tabular}

\section{Discussion}

It is clear that the current generation of child caregivers were victims of corporal punishment and that they also inflict corporal punishment on children. These results are consistent with those reported in previous studies (Allen Carroll et al., 2016; Brennen et al., 2016). The attitudes of respondents are in favour of the use of corporal punishment in the home, even though its use can run the risk of child abuse, as harsh physical punishment was used in the four weeks prior to the study by $8.5 \%$ of caregivers. Many participants were relatively young adults, so very likely their knowledge, attitudes, and practices will be those that inform the upbringing of the next generation of Bahamians (Allen Carroll et al., 2016); therefore, corporal punishment is likely to continue to be used at least into the middle of the $21 \mathrm{st}$ century unless interventions are made.

Corporal punishment appears to be used to obtain an immediate change in the behaviour of the victim, even though respondents were less sure about its long-term benefits to change behaviour. Further, respondents appeared to have conflicting views on corporal punishment, as illustrated in Table 6, while respondents acknowledge the limitations of corporal punishment in terms of its long-term benefits, they also seemed to recognize that victims of corporal punishment would inflict corporal punishment on their children; an observation confirmed in this study as most participants had been victims of corporal punishment and, as caregivers, had used a similar method of discipline on those in their care.

Of interest is that female respondents indicated less agreement with the outcomes of corporal punishment than males, even though females are the primary persons who 
administer corporal punishment (Fielding et al., 2015). This probably reflects the longstanding tensions arising from mothers who are heads of households or caregivers and also employed (Hahnlen et al., 1997).

Drivers of the use of the corporal punishment appear to include faith-based teachings, typically the Christian Bible and social norms related to what defines a good parent, but there was also some ambivalence on this latter point, as indicated by Participant E and Participant I. Given the reliance of Bahamians on the Jewish Scriptures (Christian Old Testament) for justifying the use violence on their children, it is noteworthy that the views of Jews themselves on the use of corporal punishment indicate there are tensions today regarding its use (Shmueli, 2010), a tension present in the statement of Participant B.

Social expectations appear to value the supposed outcomes of corporal punishment: well-behaved children. Overall, this is consistent with the use of corporal punishment in schools, which emphasizes behaviour rather than learning as the rationale for using corporal punishment (Fielding \& Ballance, 2020). In both school and home settings, the emphasis is on the immediate behaviour of the child rather than longer-term outcomes, including whether the use of violence actually changes the behaviour of the child in the long term. Corporal punishment is regulated in the public school system (Johnson, 2016), but participants were divided as to whether there should be limitations placed on the way parents bring up their children. The privacy of the home and what happens there as something that should be protected has been highlighted by government officials with respect to other aspects of violence in the home, particularly marital rape ("Lanisha Rolle," 2017). This might suggest that the reach of the law is subject to limitations.
It is apparent that the direct experiences of participants as well as social expectations probably influenced the actions and attitudes of participants towards the use of corporal punishment. This is consistent with studies from elsewhere, such as Walker et al. (2021). It is also evident that many participants did not know about the potential harm to which children are exposed through the use of corporal punishment. While women were more aware than men of the negative risks associated with corporal punishment, typically less than half of the male and female respondents were knowledgeable of such matters. This observation is important because lawmakers have advocated that the public should decide if corporal punishment of children should continue to be permitted (Strachan, 2019).

This study indicates that the public does not show much awareness of the long-term consequences of corporal punishment (Table 6) or even the short-term risks (Hardt et al., 2008), and they run the risk of advocating for its continued use while being unaware of the long-term unintended consequences of their actions on their children. The linkage between lack of knowledge about the effects of corporal punishment and discipline practices should not be overlooked. Before any public consultation is carried out with respect to legislating the use of corporal punishment, the public would need to be made aware of the implications of hitting their children.

As demonstrated by Robinson et al. (2005), educating people on the effects of corporal punishment can successfully change attitudes towards it. Irrespective of any moves to legally protect children from violence in the home, it is clear that parents and children should be better informed on the dangers associated with inflicting corporal punishment on children and related parenting practices of concern. 
Although parenting styles and practices were not the focus of this study, disciplining methods do form part of parenting styles. Jones et al. (2012) investigated parenting practices in The Bahamas and indicated that increased parental monitoring was advantageous to the child, but they did not look at child discipline. Caregivers in The Bahamas appear to use a mix of positive and negative parenting practices, a finding in agreement with Lipps et al. (2012), whose study included parents in The Bahamas. Lipps et al. (2012) also noted the link between negative parenting practices and depression in adolescents, which reinforces the long-term consequences associated with such parenting. The use of psychological aggression was more common than corporal punishment, a finding that is consistent with a study on young children using global data (Cuartas et al., 2019). Like corporal punishment, psychological aggression is also associated with negative consequences for the child (Wang \& Kenny, 2014) and its effects are considered more of a concern than physical aggression (Miller-Perrina et al.,
2009). Kuppens et al. (2013) identified a link between parental psychological control and violence in the child. The fact that such aggression does not leave physical marks may make it more concerning than hitting, particularly since it can put the child at risk of becoming a violent adult, but its use is less visible due to the lack of physical evidence. This aspect of child rearing in The Bahamas would appear to warrant further investigation, particularly in the light of child suicide (Smith-Cartwright, 2020) and the new awareness concerning stress in the community following Hurricane Dorian in 2019 (Rolle, 2019) and the Covid-19 pandemic in 2020 (Hutcheson et al., 2020).

A limitation of the study results is that they possibly arise from a biased sample of adult Bahamians in The Bahamas, as it was an Internet study in which participants were recruited via social media. However, triangulation of the results with other studies suggests that the bias should not be sufficient to invalidate the inferences.

\section{Acknowledgements}

The authors are grateful to the Social Research Methods class of Fall 2020 for its assistance in the data collection and for its input into the final survey form. The authors appreciate the comments of Dr. Shane Brennen, who read an earlier draft of this paper.

\section{References}

Allen Carroll, M. A., Fielding, W. J.,

Brennan, S., \& Hutcheson, S. P. (2016).

Rearing violence: Violence toward children at home. In W. J. Fielding, V. C.

F. Ballance, \& I. G. Strachan (Eds.), Violence in The Bahamas (pp. 31-62). University of The Bahamas. https://ufdc.ufl.edu/AA00078778/00005
Barrow, C., \& Ince, M. (2008). Early childhood in the Caribbean. (Working Papers in Early Childhood Development, 47). https://resourcecentre.savethechildren.net/ sites/default/files/documents/5167.pdf

Brennen, S., Fielding, W. J., Carroll, M. C., McCants-Miller, J. C., Adderley, L., \& 
Thompson, M. A. (2016). A preliminary investigation of the prevalence of corporal punishment of children and selected cooccurring behaviours in households on New Providence, The Bahamas. In W. J. Fielding, V. C. F. Ballance, \& I. G. Strachan (Eds.), Violence in The Bahamas (pp. 63-78). University of The Bahamas. https://ufdc.ufl.edu/AA00078778/00006

Burke, T., \& Kuczynski, L. (2018). Jamaican mothers' perceptions of children's strategies for resisting parental rules and requests. Frontiers in Psychology, 9(1786), 1-12.

https://doi.org/10.3389/fpsyg.2018.01786

Cuartas, J., McCoy, D. C., Rey-Guerra, C., Britto, P. R., Beatriz, E., \& Salhi, C. (2019). Early childhood exposure to nonviolent discipline and physical and psychological aggression in low-and middle-income countries: National, regional, and global prevalence estimates. Child Abuse \& Neglect, 92, 93-105. https://doi.org/10.1016/j.chiabu.2019.03.0 21

Dede Yildirim, E. (2013). Relationships between parenting styles, severity of punishment, importance of religion in child development and childhood social behaviors in Caribbean immigrant families [Doctoral dissertation, Syracuse University].

https://surface.syr.edu/thesis/5

Dede Yildirim, E., \& Roopnarine, J. L. (2019). Positive discipline, harsh physical discipline, physical discipline and psychological aggression in five Caribbean countries: Associations with preschoolers' early literacy skills. International Journal of Psychology, 54(3), 342-350. https://doi.org/10.1002/ijop.12465
Deveaux, L., Rolle, G. (2016). The Focus on Youth prevention and education research programme. International Journal of Bahamian Studies, 22, 91-98. https://doi.org/10.15362/ijbs.v22i0.276

Early Childhood Care Act (2004) and Early Childhood Care (National Standards) Regulations (2015) Bahamas. https://www.cavehill.uwi.edu//LAWLIBR ARY/getattachment/85786aa5-589b48e8-84e1-78f986ce414a/EARLYCHILDHOOD-CARE-ACT.aspx

Fielding, W. J. (2016). Violence in the life of an inmate prior to conviction and its association with crimes against persons. In W. J. Fielding, V. C. F. Ballance, \& I. G. Strachan (Eds.), Violence in The Bahamas (pp. 205-220). University of The Bahamas. https://ufdc.ufl.edu/AA00078778/00015

Fielding, W. J. (2020). Bullying in the Bahamian workplace. International Journal of Bahamian Studies, 26, 13-32. https://doi.org/10.15362/ijbs.v26i0.355

Fielding, W. J., \& Ballance, V. C. (2019). Learning gender-based attitudes in The Bahamas. International Journal of Bahamian Studies, 25, 2-15. https://doi.org/10.15362/ijbs.v25i0.339

Fielding, W. J., \& Ballance, V. C. (2020). A review of the literature on corporal punishment in The Bahamas, with an emphasis on its use in schools. International Journal of Bahamian Studies, 26, 113-130. https://doi.org/10.15362/ijbs.v26i0.353

Fielding, W. J., Ballance, V. C. F., \& Strachan I. G. (Eds.). (2016). Violence in The Bahamas. University of The Bahamas. https://ufdc.ufl.edu/AA00078778/00001 
Fielding, W. J., Risley-Curtiss, C., \& Cronin, T. W. (2015). A cross-cultural comparison of interpersonal violence in the lives of college students from two colleges from The Bahamas and United States of America. International Journal of Bahamian Studies, 21(1), 38-56. https://doi.org/10.15362/ijbs.v21i1.230

Gershoff, E. T. (2010). More harm than good: A summary of scientific research on the intended and unintended effects of corporal punishment on children. Law \& Contemporary Problems, 73, 31-56. https://core.ac.uk/download/pdf/62553074 .pdf

Hahnlen, N. C., Rosado, M. S., Capozzi, K. A., \& Hamon, R. R. (1997, November). Mothering in The Bahamas: A student ethnography. Paper presented at the 59th Annual National Council on Family Relations Conference, Arlington, Virginia. http://files.eric.ed.gov/fulltext/ED417004. pdf

Hardt, J., Sidor, A., Nickel, R., Kappis, B., Petrak, P., \& Egle, U. (2008). Childhood adversities and suicide attempts: A retrospective study. Journal of Family Violence, 23(8), 713-718. https://doiorg/10.1007/s10896-008-9196-1

Hutcheson, S. P., Hall Campbell Dean, N., \& Fielding, W. (2020, June 8). Cocktail of factors leaves one in four adults highly stressed. The Tribune. http://www.tribune242.com/news/2020/ju n/08/insight-cocktail-factors-leaves-onefour-adults-hi/

Johnson, P. (2016). Violence in schools. In W. J. Fielding, V. C. F. Ballance, \& I. G. Strachan (Eds.), Violence in The Bahamas (pp. 205-220). University of The
Bahamas. https://ufdc.ufl.edu/AA00078778/00010

Jones, G., Chen, X., Stanton, B., Dinaj-Koci, V., Deveaux, L., Lunn, S., Brathwaite, N., \& Gomez, M. P. (2012). Parental monitoring and risky behavior in Bahamian youth. International Journal of Child, Youth \& Family Studies, 3(4), 376395.

https://doi.org/10.18357/ijcyfs342012114 83

Knowles, L. A. M. (1999). Impact of physical abuse on the psychological and behavioural state of institutionalized children in The Bahamas and Jamaica [Unpublished doctoral dissertation]. University of the West Indies, Mona, Jamaica.

http://uwispace.sta.uwi.edu/dspace/handle /2139/2346

Kuppens, S., Laurent, L., Heyvaert, M., \& Onghena, P. (2013). Associations between parental psychological control and relational aggression in children and adolescents: A multilevel and sequential meta-analysis. Developmental Psychology, 49(9), 1697-1712. https://doi.org/10.1037/a0030740

Landon, B. G., Waechter, R., Wolfe, R., \& Orlando, L. (2017). Corporal punishment and physical discipline in the Caribbean: Human rights and cultural practices. Caribbean Journal of Psychology, 9(1), 7-23.

https://www.researchgate.net/profile/Barb ara_Landon/publication/331207188_Corp oral_Punishment_and_Physical_Disciplin e_in_the_Caribbean_Human_rights_and_ cultural_practices/links/5c6c160692851c1 c9dec4637/Corporal-Punishment-andPhysical-Discipline-in-the-CaribbeanHuman-rights-and-cultural-practices.pdf 
Lanisha Rolle: Marital rape is a private issue. (2017, December 20). The Nassau Guardian. https://thenassauguardian.com/2017/12/20 /rolle-marital-rape-is-a-private-issue/

Lipps, G., Lowe, G. A., Gibson, R. C., Halliday, S., Morris, A., Clarke, N., \& Wilson, R. N. (2012). Parenting and depressive symptoms among adolescents in four Caribbean societies. Child and Adolescent Psychiatry and Mental Health, 6(1), 1-12. https://doi.org/10.1186/17532000-6-31

Miller-Perrina, C. L., Perrina, R. D., \& Kocurb, J. L. (2009). Parental physical and psychological aggression:

Psychological symptoms in young adults. Child Abuse \& Neglect, 33(1), 1-11. https://doi.org/10.1016/j.chiabu.2008.12.0 01

Otterbein, C. S., \& Otterbein, K. F. (1973). Believers and beaters: A case study of supernatural beliefs and child rearing in the Bahama Islands. American Anthropologist, 75(5), 1670-1681. https://doi.org/10.1525/aa.1973.75.5.02a0 0290

Payne, M. A. (1989). Use and abuse of corporal punishment: A Caribbean view. Child Abuse \& Neglect, 13(3), 389-401. https://doi.org/10.1016/01452134(89)90079-3

Residential Care Establishments Act (2004) Bahamas (Ch. 235A). http://laws.bahamas.gov.bs/cms/images/L EGISLATION/PRINCIPAL/2004/20040024/ResidentialCareEstablishmentsAct_ 1.pdf

Robinson, D. H., Funk, D. C., Beth, A., \& Bush, A. M. (2005). Changing beliefs about corporal punishment: Increasing knowledge about ineffectiveness to build more consistent moral and informational beliefs. Journal of Behavioral Education, 14(2), 117-139. https://doi.org/10.1007/s10864-005-27069

Rolle, L. (2019, October 11) Nation will face a mental health impact from storm. The Tribune. http://www.tribune242.com/news/2019/oc $\mathrm{t} / 11 /$ nation-will-face-a-mental-healthimpact-from-storm/

Roth, R. M., Abecassis, M., Isquith, P. K., \& Fielding, W. J. (2020, February 5-8). Corporal punishment in childhood is associated with self-rated executive functions in Bahamian college students [Poster presentation]. International Neuropsychological Society Meeting, Denver, Colorado. https://www.theins.org/meetings/denver20 20/

Save the Children. (2015). Ending corporal punishment of children: A handbook for working with religious communities. Global Initiative to End All Corporal Punishment of Children. http://endcorporalpunishment.org/wpcontent/uploads/thematic/Religiouscommunities-handbook-abridged2015.pdf

Shmueli, B. (2010). Corporal punishment of children in Jewish law. Jewish Law Annual, 18, 137-212. https://ssrn.com/abstract=1514336

Smith, D. E. (2016). Corporal punishment of children in the Jamaican context. International Journal of Child, Youth and Family Studies, 7(1), 27-44. https://doi.org/10.18357/ijcyfs.712016154 15 
Smith, D. E., \& Mosby, G. (2003). Jamaican child-rearing practices: The role of corporal punishment. Adolescence, 38(150), 369-381.

Smith, S. (2021, February 3). Campbell: No more corporal punishment in children's homes. Eyewitness News. https://ewnews.com/campbell-no-morecorporal-punishment-in-childrens-homes

Smith-Cartwright, T. (2020, December 7). No time to play a blame game. The Tribune. http://www.tribune242.com/news/2020/de c/07/no-time-play-blame-game/?news

Strachan, M. (2019, June 17). The grey area of corporal punishment in schools may have made one administrator a sacrificial lamb. The Tribune. http://www.tribune242.com/news/2019/ju n/17/insight-grey-area-corporalpunishment-schools-may-/

Sutton, H., \& Álvarez, L. (2016). How safe are Caribbean homes for women and children?: Attitudes toward intimate partner violence and corporal punishment. Inter-American Development Bank. https://doi. org/10.18235/0000546

UNICEF. (1989). The United Nations Convention on the Rights of the Child. https://www.unicef.org.uk/rightsrespecting-schools/wpcontent/uploads/sites/4/2017/01/UNCRCin-full.pdf
UNICEF. (2017). Survey on parents' and caregivers' knowledge, attitudes, practices and social norms associated with violence against children:

Professional groups. https://www.unicef.org/northmacedonia/m edia/4251/file/MK_KAPProfessionals_Re port_ENG. pdf

Walker, C. S., Stearns, M., \& McKinney, C. (2021). Effect of parental corporal punishment on endorsement of its use: Moderated mediation by parent gender and attitudes toward corporal punishment. Journal of Interpersonal Violence, 36(1314), 6745-6768. https://doi.org/10.1177/088626051881987 8

Wang, M. T., \& Kenny, S. (2014). Longitudinal links between fathers' and mothers' harsh verbal discipline and adolescents' conduct problems and depressive symptoms. Child Development, 85(3), 908-923.

https://doi.org/10.1111/cdev.12143

Zolotor, A. J., Theodore, A. D., Chang, J. J., Berkoff, M. C., \& Runyan, D. K. (2008). Speak softly - and forget the stick: Corporal punishment and child physical abuse. American Journal of Preventive Medicine, 35(4), 364-369. https://doi.org/10.1016/j.amepre.2008.06. 031 